\title{
CD166 Antigen
}

National Cancer Institute

\section{Source}

National Cancer Institute. CD166 Antigen. NCI Thesaurus. Code C17920.

CD166 antigen (583 aa, $\sim 65 \mathrm{kDa}$ ) is encoded by the human ALCAM gene. This protein is involved in cell adhesion. 